\title{
Surgeon and Preparedness for COVID-19 Pandemic
}

\section{Sora Yasri ${ }^{1} \cdot$ Viroj Wiwanitkit ${ }^{2}$}

Received: 24 April 2020 / Accepted: 30 April 2020 / Published online: 13 May 2020

(C) Association of Surgeons of India 2020

Dear Editor,

We found that the publication on "Are Surgeons in India prepared for COVID-19?" is very interesting [1]. Bhattacharya noted that "Given the number of surgeries done in India, it is mandatory for the surgical team to be adequately protected from virus transmission during the COVID-19 outbreak [1]." In fact, surgeon has a high risk for getting COVID9 during occupational practice. The COVID-19 patient might be asymptomatic and might transmit disease to the surgeon [2]. Several recommendations by Bhattacharya are useful. The implementation of the preventive actions is a challenge. Reallocation of staffs and facilities to correspond to the crisis is needed. Here, we would like to share ideas from Inchina where disease outbreak is also serious. Due to the long period of outbreak, some surgeons already got infection. The lack of protective device is the main problem. Also, some practitioners might follow only local guideline for screening for COVID-19. According to local criteria, fever is the main determinant; hence, the under diagnosis of asymptomatic case is possible and results in infection among medical personnel.
The infection control process should be universal and applied for all cases in all settings.

\section{Compliance with Ethical Standards}

Conflict of Interest The authors declare that they have no conflict of interest.

\section{References}

1. Bhattacharya K (2020) Are surgeons in India prepared for COVID19? Indian J Surg 17:1-2. https://doi.org/10.1007/s12262-02002185-Z

2. Joob B, Wiwanitkit V (2020) Carpal fracture and COVID-19 infection: observation from Thailand. Indian J Orthop 21:1. https://doi. org/10.1007/s43465-020-00112-8

Publisher's Note Springer Nature remains neutral with regard to jurisdictional claims in published maps and institutional affiliations.
Sora Yasri

sorayasri@outlook.co.th

KMT Primary Care Center, Bangkok, Thailand

2 Dr DY Patil University, Pune, India 